\title{
Evaluasi Nutrisi Tepung Ikan Rucah yang Diolah Menggunakan Probiotik dan Precursor-Prebiotik dalam ransum Ayam Broiler
}

\section{Nutritional Evaluation of Trash Fish Meal Processed Using Probiotics and Prebiotic- Precursors in Broiler Diet}

\author{
E. Hendalia, F. Manin, dan Adriani \\ Fakultas Peternakan Universitas Jambi \\ Corresponding Author: ella hendalia@unja.ac.id
}

\begin{abstract}
This study aimed to evaluate the nutritional quality of trash fish meal (FM) processed using lactic acid bacteria probiotic (PRO) combined with prebiotic precursor i.e. coconut meal (CM) or palm kernel meal (PKM) in broiler diet. A total of 384 one-day-old chicks (MB 202-P) unsexed, were randomly assigned into 32 pens (12 chickens/pen) according to $2 \times 3$ factorial completely randomized design plus one control, each consisting of 4 replications (except control 8 replications). The first factor were two types of the FM (FM-PRO-CM and FMPRO-PKM) and the second were three levels of their usage $(5 \% ; 7.5 \%$; and $10 \%)$ replacing of commercial FM (FM-COM). A control diet was formulated using 10\% FM-COM. The result showed that the use of FM-PRO-CM $10 \%$ and FM-PRO-PKM $10 \%$ resulted in a higher $(\mathrm{P}<0.05)$ growth performance, carcass weight, breast meat weight, and protein efficiency ratio compared to FM- COM 10\%; however, there was no significant effect on the number of Lactobacillus sp. and E. coli in the intestinal fluid. It was concluded that the FM-PRO-CM and FMPRO-PKM had a better nutritional quality compared to the FM-COM, so it has the potential to be used as source of protein as well as source of probiotic, prebiotic and postbiotic in broiler diet.
\end{abstract}

Key words: fish meal, prebiotic, probiotic, postbiotic

\begin{abstract}
ABSTRAK
Penelitian ini bertujuan untuk mengevaluasi kualitas nutrisi tepung ikan rucah (TI) yang diolah menggunakan probiotik bakteri asam laktat (PRO) dikombinasikan dengan precursor prebiotik berupa bungkil kelapa (BK) atau bungkil inti sawit (BIS) dalam ransum ayam broiler. Sebanyak 384 ekor ayam umur satu hari (MB 202-P) unsexed, didistribusikan ke dalam 32 unit kandang koloni (12 ekor/unit), menurut rancangan acak lengkap faktorial 2 × 3 dengan empat ulangan (kecuali kontrol 8 ulangan). Faktor pertama adalah penggunaan 2 jenis TI (TI-PRO-BK dan TI-PRO-BIS), sedangkan faktor ke-dua adalah 3 taraf penggunaannya di dalam ransum (5\%; 7,5\%; dan 10\%) menggantikan TI-KOM. Ransum kontrol diformulasikan menggunakan TI-KOM 10\% (tanpa TI-PRO). Hasil penelitian menunjukkan bahwa penggunaan TI-PRO-BK 10\% dan TI-PRO-BIS $10 \%$ dalam ransum ayam broiler menghasilkan performan pertumbuhan, bobot karkas, bobot daging dada, dan efisiensi penggunaan protein yang nyata lebih tinggi $(\mathrm{P}<0,05)$ dibandingkan TI-KOM 10\%, namun tidak nyata dalam mempengaruhi jumlah Lactobacillus dan E. coli di dalam cairan usus. Disimpulkan bahwa TI-PRO-BK dan TIPRO-BIS memiliki kualitas nutrisi yang lebih baik dibandingkan dengan TI-KOM, sehingga berpotensi untuk digunakan sebagai sumber protein sekaligus sumber probiotik, prebiotik dan postbiotic dalam pakan ayam broiler.
\end{abstract}

Kata kunci: tepung ikan, probiotik, prebiotik, postbiotic

\section{PENDAHULUAN}

Permasalahan utama dalam memproduksi tepung ikan lokal adalah rendahnya kualitas bahan baku (ikan rucah), kurang praktisnya teknik pengolahan, serta timbulnya bau limbah yang mencemari lingkungan. Untuk mengatasi ketiga permasalahan tersebut, cara yang dapat dilakukan adalah mengolah tepung ikan secara langsung dari ikan mentah menggunakan probiotik bakteri asam laktat dikombinasikan dengan pakan sumber prebiotik seperti bungkil kelapa (BK) atau bungkil inti sawit (BIS) (Manin et al., 2018), sehingga akan dihasilkan tepung ikan (TI) yang mengandung probiotik (TI-PRO) (Hendalia et al., 2019a). Pengolahan TI-PRO dilakukan tanpa menggunakan garam, tanpa bahan pengawet, serta tanpa melalui proses pengukusan/perebusan dan pengepresan, sehingga tidak menyebabkan terjadinya denaturasi protein serta hilangnya nutrient terlarut, seperti asam amino, vitamin, mineral dan asam lemak esensial. Selain praktis untuk dilakukan, pengolahan dengan cara ini juga 
tidak banyak menghasilkan limbah yang mencemari lingkungan.

Ditinjau dari aspek nutrisi, pengolahan TI-PRO memiliki banyak keuntungan dibandingkan dengan pengolahan tepung ikan secara konvensional, karena selain dapat mempertahankan kualitas nutrisi ikan, teknik ini juga akan menghasilkan tepung ikan yang mengandung probiotik, prebiotik dan postbiotik (Hendalia et al., 2019a; b). Postbiotic yang disekresikan oleh bakteri asam laktat (BAL) dapat berupa asam laktat, asam propionate, asam butirat, bakteriosin, enzim, senyawa antioksidan dan berbagai senyawa metabolit lainnya (Thanh et al., 2009; Manin, 2010; Thu et al., 2011; Loh et al., 2014; Chuah et al., 2019; Yang et al., 2020). Postbiotik dilaporkan dapat berperan sebagai natural biopreservatives (Jama and Varadaraj 1999, Hidayatulloh et al., 2019), dan antibiotic growth promoters baik pada ayam petelur, maupun ayam pedaging (Thanh et al., 2009; Loh et al., 2014; Goh et al., 2020).

Hasil penelitian terdahulu (Hendalia et al., 2019a; b), menunjukkan bahwa tepung ikan rucah yang diolah menggunakan probiotik BAL dikombinasikan dengan sumber prebiotik bungkil kelapa (TI-PRO-BK) atau bungkil inti sawit (TIPRO-BIS) mengandung Lactobacillus sp. 1,0$6,1 \times 10^{10} \mathrm{cfu} / \mathrm{gr}$ dan bebas Salmonella. Secara fisik kedua TI-PRO tersebut memiliki aroma khas tepung ikan, bertekstur renyah, tidak berminyak, tidak menggumpal, tidak bulky serta tidak menunjukkan perubahan penampakan dan ketengikan setelah disimpan selama 4 bulan (Hendalia et al., 2019a), bahkan lebih dari 12 bulan (data pribadi). Kandungan protein TI-PRO sangat bervariasi tergantung keragaman jenis ikan (43,77-62,38\%) dengan kandungan energi bruto $4354-4529 \mathrm{kkal} / \mathrm{kg}$. Dilihat dari komposisi asam aminonya, TI-PRO defisien akan arginin, valin dan tryptophan, namun mengandung metionin yang lebih tinggi dibandingkan tepung ikan menurut NRC 1994 (Hendalia et al., 2019b). Untuk mengevaluasi kualitas biologis TI-PRO perlu dilakukan feeding trial pada ternak.

Penelitian ini bertujuan untuk mengevaluasi kualitas nutrisi TI-PRO-BK (mengandung protein kasar 62,38\% ) dan TIPRO-BIS (mengandung protein kasar 57,15\%) dibandingkan dengan tepung ikan komersil (TIKOM) (mengandung protein kasar 65,98\%) dalam ransum ayam broiler berdasarkan parameter performan pertumbuhan, efisiensi penggunaan protein dan mikrobiologi isi saluran pencernaan. Dari hasil penelitian ini diharapkan dapat diperoleh informasi tentang potensi penggunaan TI-PRO untuk menggantikan penggunaan tepung ikan komersil di dalam ransum unggas, khususnya ayam broiler.

\section{MATERI DAN METODE}

Pada penelitian ini digunakan DOC strain MB 202-P unsex sebanyak 384 ekor. Ikan rucah untuk pembuatan TI-PRO diperoleh dari nelayan di Kabupaten Tanjung Jabung Barat Provinsi Jambi, bungkil kelapa diperoleh dari pabrik pengolahan minyak kelapa di Kabupaten Tanjung Jabung Barat, dan bungkil inti sawit diperoleh dari PT. Kresna Duta Agroindo (KDA) di Kabupaten Sarolangun Provinsi Jambi. Probiotik yang digunakan adalah Probio FM (Manin et al. 2014), terdiri atas empat spesies BAL (L. plantarum, $L$. fermentum, $L$. brevis, dan Pediococcus pentosaceus) dengan jumlah bakteri $10^{10}-10^{11}$ $\mathrm{cfu} / \mathrm{ml}$. Tepung ikan komersil (TI-KOM) yang digunakan sebagai pembanding dan bahan pakan penyusun ransum lainnya diperoleh dari PT. Indofeed Bogor.

Sebelum dilakukan feeding trial, terlebih dahulu dilakukan pembuatan TI-PRO-BK dan TIPRO-BIS (Hendalia et al., 2019a). Ikan rucah dicampur dengan sumber prebiotik (BK atau BIS) sebanyak 10\% dan probiotik Probio_FM sebanyak $2 \%(\mathrm{v} / \mathrm{w})$ dari berat ikan, kemudian digiling menggunakan mesin penggiling ikan. Hasil gilingan dijemur di bawah sinar matahari atau oven $\left(40-45{ }^{\circ} \mathrm{C}\right)$ (untuk menjaga viabilitas bakteri). Selama proses pengeringan tepung ikan dibolak-balik agar pengeringannya terjadi secara merata. Ikan yang sudah kering kemudian digiling kembali menjadi tepung. Hasil analisis kimia TIPRO dan TI-KOM disajikan pada Tabel 1.

Pengujian biologis TI-PRO dilakukan menggunakan rancangan acak lengkap pola faktorial $2 \times 3$ ditambah satu kontrol, masingmasing terdiri atas 4 ulangan (kecuali kontrol 8 ulangan), setiap ulangan terdiri atas 12 ekor ayam. Faktor pertama adalah penggunaan 2 jenis TIPRO (TI-PRO-BK dan TI-PRO-BIS), sedangkan faktor ke dua adalah 3 taraf penggunaannya di dalam ransum $(5 \%, \quad 7,5 \%$ dan $10 \%)$ menggantikan tepung ikan komersil (TI-KOM). Sebagai kontrol digunakan ransum yang mengandung 10\% TI-KOM (tanpa TI-PRO). 
Tabel 1. Kandungan nutrient TI-PRO-BK, TI-PRO-BIS dan TI-KOM dalam bahan kering

\begin{tabular}{|c|c|c|c|}
\hline Nutrien $^{1)}$ & TI-PRO-BK & TI-PRO-BIS & TI-KOM \\
\hline \multicolumn{4}{|l|}{ Nutrien } \\
\hline Abu (\%) & 19.04 & 17.18 & 19.61 \\
\hline Protein kasar (\%) & 62.38 & 57.15 & 65.98 \\
\hline Serat kasar (\%) & 3.33 & 7.63 & 8.52 \\
\hline Ekstrak Eter (\%) & 5.94 & 5.03 & 5.87 \\
\hline BETN (\%) & 8.47 & 13.02 & 0.02 \\
\hline kalsium (\%) & 4.77 & 4.52 & 9.21 \\
\hline Fosfor $(\%)$ & 2.40 & 2.28 & 2.03 \\
\hline Gross Energy (kcal/g & 4478 & 4467 & - \\
\hline ME $(72.5 \%$ GE) $(\mathrm{kkal} / \mathrm{kg})$ & 3246 & 3238 & \\
\hline \multicolumn{4}{|l|}{ Asam Amino } \\
\hline Asam aspartat (\%) & 3.88 & 1.26 & 3.29 \\
\hline Asam glutamat (\%) & 5.12 & 2.29 & 6.73 \\
\hline Serin $(\%)$ & 2.00 & 1.14 & 1.84 \\
\hline Glisin (\%) & 3.01 & 1.38 & 1.23 \\
\hline Histidin (\%) & 2.57 & 0.96 & 1.12 \\
\hline Arginin (\%) & 1.51 & 0.93 & 1.54 \\
\hline Treonin (\%) & 0.84 & 0.81 & 1.08 \\
\hline Alanin (\%) & 0.69 & 0.73 & 1.61 \\
\hline Prolin (\%) & 2.79 & 0.88 & 1.45 \\
\hline Tirosin $(\%)$ & 1.68 & 0.74 & 1.32 \\
\hline Valin (\%) & 1.55 & 0.82 & 1.25 \\
\hline Metionin (\%) & 1.80 & 0.89 & 0.98 \\
\hline Sistein (\%) & 1.13 & 0.67 & 1.04 \\
\hline Isoleusin (\%) & 1.63 & 0.79 & 1.52 \\
\hline Leusin $(\%)$ & 3.21 & 1.19 & 2.78 \\
\hline Fenilalanin (\%) & 1.69 & 0.73 & 1.12 \\
\hline $\operatorname{Lisin}(\%)$ & 3.04 & 1.29 & 2.21 \\
\hline \multicolumn{4}{|l|}{ Asam lemak ${ }^{4)}$} \\
\hline Oleat & 49.63 & 26.29 & 29.66 \\
\hline Linoleat & 0.43 & 0.12 & 0.52 \\
\hline Linolenat & 0.05 & $\mathrm{Nd}$ & 0.11 \\
\hline
\end{tabular}

Keterangan: ${ }^{1)}$ Hasil analisis Laboratorium IPTP, Fakultas Peternakan Institut Pertanian Bogor (2019)

Komposisi bahan pakan dan zat makanan di dalam ransum perlakuan disajikan pada Tabel 2. Ransum perlakuan dan air minum diberikan $a d$ libitum selama 35 hari. Pada akhir penelitian dilakukan pemotongan ayam, kemudian dilakukan pengambilan sampel cairan usus untuk pengujian mikrobiologi, serta penimbangan karkas dan daging dada.

Peubah yang diamati meliputi performans ayam broiler (konsumsi ransum, pertambahan bobot badan, dan konversi pakan), bobot potong, bobot karkas, bobot daging dada, ratio efisiensi protein, dan mikrobiologi cairan usus halus (jumlah koloni Lactobacillus sp, E. Coli, dan $\mathrm{pH}$ cairan usus). Analisis proksimat, energi bruto, asam amino dan asam lemak dilakukan di Laboratorium Ilmu dan Teknologi Pakan Fakultas Peternakan Institut Pertanian Bogor (terakreditasi KAN: LP-1140-IDN), sedangkan analisis mikrobiologi dilakukan di Laboratorium Kesehatan Hewan Fakultas Peternakan Universitas Jambi.

Data dianalisis menggunakan analisis varian (ANOVA) dua jalur dalam rancangan acak lengkap pola faktorial, sedangkan untuk membandingkan perbedaan antara perlakuan dengan kontrol dilakukan analisis varian satu jalur dengan post hoc Duncan's multiple range test pada tingkat probabilitas $5 \%$ menggunakan program SPSS versi 24. 
Table 2. Komposisi bahan pakan dan nutrien di dalam ransum perlakuan

\begin{tabular}{|c|c|c|c|c|c|c|c|}
\hline \multirow{3}{*}{ Bahan pakan (\%) } & \multicolumn{7}{|c|}{ Ransum perlakuan } \\
\hline & \multicolumn{3}{|c|}{ TI-PRO-BK } & \multicolumn{3}{|c|}{ TI-PRO-BIS } & \multirow{2}{*}{$\frac{\text { KONTROL }}{\text { TI-KOM }}$} \\
\hline & $5 \%$ & $7.5 \%$ & $10 \%$ & $5 \%$ & $7.5 \%$ & $10 \%$ & \\
\hline TI-PRO-BK & 5.00 & 7.50 & 10.00 & 0.00 & 0.00 & 0.00 & 0.00 \\
\hline TI-PRO-BIS & 0.00 & 0.00 & 0.00 & 5.00 & 7.50 & 10.00 & 0.00 \\
\hline TI-KOM & 5.00 & 2.50 & 0.00 & 5.00 & 2.50 & 0.00 & 10.00 \\
\hline Poles & 2.00 & 2.00 & 2.00 & 2.00 & 2.00 & 2.00 & 2.00 \\
\hline Jagung kuning & 57.00 & 57.00 & 57.00 & 57.00 & 57.00 & 57.00 & 57.00 \\
\hline Bungkil kedelai & 27.00 & 27.00 & 27.00 & 27.00 & 27.00 & 27.00 & 27.00 \\
\hline Minyak sawit & 2.00 & 2.00 & 2.00 & 2.00 & 2.00 & 2.00 & 2.00 \\
\hline Top mix & 0.25 & 0.25 & 0.25 & 0.25 & 0.25 & 0.25 & 0.25 \\
\hline Natrium klorida & 0.25 & 0.25 & 0.25 & 0.25 & 0.25 & 0.25 & 0.25 \\
\hline Kalsium karbonate & 1.00 & 1.00 & 1.00 & 1.00 & 1.00 & 1.00 & 1.00 \\
\hline Mineral mix & 0.25 & 0.25 & 0.25 & 0.25 & 0.25 & 0.25 & 0.25 \\
\hline DL-Methioine & 0.10 & 0.10 & 0.10 & 0.10 & 0.10 & 0.10 & 0.10 \\
\hline L-Lysine & 0.15 & 0.15 & 0.15 & 0.15 & 0.15 & 0.15 & 0.15 \\
\hline Total & 100 & 100 & 100 & 100 & 100 & 100 & 100 \\
\hline \multicolumn{8}{|c|}{ Kandungan Nutrien ${ }^{1)}$} \\
\hline $\operatorname{ME}(\mathrm{kcal} / \mathrm{g})$ & 3052 & 3045 & 3038 & 3058 & 3055 & 3051 & 3066 \\
\hline Bahan kering $(\%)$ & 89.22 & 89.14 & 89.06 & 89.50 & 89.55 & 89.61 & 89.38 \\
\hline Protein kasar (\%) & 22.56 & 22.45 & 22.34 & 22.47 & 22.30 & 22.14 & 22.79 \\
\hline Serat kasar (\%) & 3.74 & 3.63 & 3.51 & 3.95 & 3.93 & 3.92 & 3.98 \\
\hline Lemak kasar (\%) & 5.11 & 5.11 & 5.11 & 5.09 & 5.07 & 5.06 & 5.12 \\
\hline Met $(\%)$ & 0.51 & 0.53 & 0.55 & 0.47 & 0.47 & 0.46 & 0.47 \\
\hline Cys $(\%)$ & 0.39 & 0.39 & 0.40 & 0.37 & 0.36 & 0.35 & 0.39 \\
\hline Met + Cys (\%) & 0.90 & 0.93 & 0.95 & 0.84 & 0.82 & 0.81 & 0.86 \\
\hline Lys (\%) & 1.30 & 1.32 & 1.34 & 1.21 & 1.19 & 1.16 & 1.26 \\
\hline $\mathrm{Ca}(\%)$ & 1.16 & 1.06 & 0.96 & 1.16 & 1.06 & 0.96 & 1.37 \\
\hline $\mathrm{P}(\%)$ & 0.56 & 0.57 & 0.57 & 0.56 & 0.57 & 0.58 & 0.55 \\
\hline
\end{tabular}

1) Perhitungan ransum berdasarkan hasil analisis proksimat Laboratorium IPTP, Fakultas Peternakan Institut Pertanian Bogor (2019)

\section{HASIL DAN PEMBAHASAN}

\section{Performans Pertumbuhan Ayam Broiler}

Data performans pertumbuhan ayam broiler, meliputi konsumsi ransum (KR), pertambahan bobot badan (PBB) dan konversi pakan atau feed convertion ratio (FCR) disajikan pada Tabel 3. Jenis TI-PRO tidak berpengaruh terhadap konsumsi ransum, pertambahan bobot badan (PBB) dan konversi pakan (FCR), sedangkan taraf penggunaan TI-PRO nyata berpengaruh terhadap peningkatan PBB dan FCR, namun tidak nyata terhadap peningkatan konsumsi ransum.

Tidak terdapat interaksi antara jenis TIPRO dan taraf penggunaannya dalam mempengaruhi konsumsi ransum, PBB dan FCR. Tidak berpengaruhnya jenis TI-PRO terhadap konsumsi ransum, PBB dan FCR menunjukkan bahwa TI-PRO-BK dan TI-PRO-BIS memilki kualitas yang relatif sama sehingga respons biologis ternak terhadap kedua TI-PRO tersebut juga relatif sama.

Hasil penelitian ini sejalan dengan hasil penelitian sebelumnya yang menunjukkan bahwa TI-PRO-BK dan TI-PRO-BIS memiliki kualitas fisik, mikrobiologi dan kimia yang relatif sama (Hendalia et al., 2019a; b). Faktor yang membedakan kedua jenis TI-PRO ini adalah sumber prebiotiknya, yaitu BK dan BIS. Baik BK ataupun BIS merupakan bahan pakan unggas yang mengandung senyawa mannan oligosakharida (MOS) sebagai prebiotik (Sundu et al., 2006). Penggunaan BK dan BIS sebagai sumber prebiotik telah terbukti dapat mendukung pertumbuhan BAL (Manin et al., 2018; Manin et al., 2019). Adanya kesesuaian antara sumber probiotik dengan sumber prebiotiknya, maka kedua TI-PRO yang dihasilkan terindikasi memiliki kualitas dan palatabilitas yang relatif sama, sehingga pengaruhnya terhadap performan pertumbuhan ternak juga relatif sama. 
Tabel 3. Pengaruh perlakuan terhadap performans pertumbuhan ayam broiler selama 35 hari

\begin{tabular}{llll}
\hline Perlakuan & $\begin{array}{l}\text { Konsumsi ransum } \\
(\mathrm{g} / \mathrm{e} / \mathrm{hr})\end{array}$ & $\begin{array}{l}\text { Pertambahan Bobot } \\
\text { Badan }(\mathrm{g} / \mathrm{e} / \mathrm{hr})\end{array}$ & $\begin{array}{l}\text { Konversi Pakan } \\
\text { FCR }\end{array}$ \\
\hline Jenis TI-PRO (A) & $\mathbf{P}>\mathbf{0 . 0 5}$ & $\mathbf{P}>\mathbf{0 . 0 5}$ & $\mathbf{P}>\mathbf{0 . 0 5}$ \\
TI-PRO-BK & $35.33 \pm 5.79$ & $18.27 \pm 3.92$ & $1.99 \pm 0.23$ \\
TI-PRO-BIS & $38.57 \pm 7.79$ & $20.34 \pm 5.51$ & $1.98 \pm 0.21$ \\
Taraf penggunaan (B) & $\mathbf{P}>\mathbf{0 . 0 5}$ & $\mathbf{P}<\mathbf{0 . 0 5}$ & $\mathbf{P}<\mathbf{0 . 0 5}$ \\
TI-PRO-5\% & $38.01 \pm 7.62$ & $18.49^{\mathrm{b}} \pm 4.49$ & $2.10^{\mathrm{b}} \pm 0.22$ \\
TI-PRO-7,5\% & $37.60 \pm 3.81$ & $20.19^{\mathrm{bc}} \pm 2.87$ & $1.93^{\mathrm{ab}} \pm 0.22$ \\
TI-PRO-10\% & $41.69 \pm 6.36$ & $23.64^{\mathrm{c}} \pm 3.98$ & $1.82^{\mathrm{a}} \pm 0.14$ \\
Interaksi (A x B) & $\mathbf{P}>\mathbf{0 . 0 5}$ & $\mathbf{P}>\mathbf{0 . 0 5}$ & $\mathbf{P}>\mathbf{0 . 0 5 6}$ \\
TI-PRO-BK 5\% & $37.85^{\mathrm{b}} \pm 8.36$ & $18.32^{\mathrm{a}} \pm 5.25$ & $2.11^{\mathrm{a}} \pm 0.32$ \\
TI-PRO-BK 7,5\% & $35.61^{\mathrm{ab}} \pm 2.84$ & $19.67^{\mathrm{bc}} \pm 2.10$ & $1.87^{\mathrm{ab}} \pm 0.23$ \\
TI-PRO-BK 10\% & $37.24^{\mathrm{b}} \pm 6.17$ & $20.76^{\mathrm{c}} \pm 2.79$ & $1.86^{\mathrm{ab}} \pm 0.10$ \\
TI-PRO-BIS 5\% & $38.16^{\mathrm{b}} \pm 8.10$ & $18.66^{\mathrm{a}} \pm 4.41$ & $2.09^{\mathrm{ab}} \pm 0.06$ \\
TI-PRO-BIS 7,5\% & $39.58^{\mathrm{bc}} \pm 3.90$ & $20.71^{\mathrm{c}} \pm 3.75$ & $1.98^{\mathrm{ab}} \pm 0.23$ \\
TI-PRO-BIS 10\% & $46.13^{\mathrm{c}} \pm 1.88$ & $26.51^{\mathrm{d}} \pm 2.69$ & $1.78^{\mathrm{b}} \pm 0.17$ \\
Kontrol & $\mathbf{P}<\mathbf{0 . 0 5}$ & $\mathbf{P}<\mathbf{0 . 0 5}$ & $\mathbf{P}>\mathbf{0 . 0 5}$ \\
TI-COM 10\% & $29.35^{\mathrm{a}} \pm 2.82$ & $14.13^{\mathrm{a}} \pm 2.24$ & $2.11^{\mathrm{a}} \pm 0.18$ \\
\hline K & & $0.05)$.
\end{tabular}

Ket: Huruf yang berbeda pada kolom yang sama menunjukkan perbedaan yang nyata $(\mathrm{P}<0,05)$.

TI-PRO-BK = Tepung ikan rucah yang diolah menggunakan probiotik BAL dengan sumber prebiotic BK; TIPRO-BIS = Tepung ikan rucah yang diolah menggunakan Probiotik BAL dengan sumber prebiotik BIS

Taraf penggunaan TI-PRO tidak memberikan pengaruh terhadap konsumsi ransum, namun secara nyata akan menghasilkan PBB yang semakin tinggi dan FCR yang semakin rendah. Artinya, semakin banyak penggunaan TIPRO menggantikan tepung ikan komersil (TIKOM) maka respons pertumbuhan ternak akan semakin baik, sehingga penggunaan pakan menjadi lebih efisien. Peningkatan PBB dan penurunan FCR pada ayam yang diberi TI-PRO dapat disebabkan oleh dua faktor, yaitu lebih tingginya kualitas protein TI-PRO dibandingkan TI-KOM serta adanya peran probiotic, prebiotik dan postbiotic di dalam saluran pencernaan ternak.

Bakteri asam laktat dilaporkan dapat menghasilkan postbiotic berupa asam-asam organic, enzim ataupun bakteriosin dilaporkan dapat memperbaiki sistem pencernaan dan penyerapan nutrient serta menyeimbangkan populasi bakteri di dalam saluran pencernaan (Thu et al., 2011; Goh et al., 2020) sehingga dapat memperbaiki performan ayam broiler. Postbiotik yang dihasilkan oleh BAL dapat digunakan untuk menggantikan antibiotic growth promoters serta telah terbukti dapat meningkatkan produktivitas dan kesehatan saluran pencernaan ayam petelur dan ayam pedaging (Thanh et al., 2009; Loh et al., 2014; Goh et al.., 2020).

Interaksi antar perlakuan tidak berpengaruh terhadap semua peubah yang diamati, namun dari hasil uji satu arah terlihat bahwa berdasarkan parameter konsumsi ransum, PBB dan FCR, penggunaan TI-PRO-BIS 10\% menghasilkan performans pertumbuhan yang nyata lebih tinggi dibandingkan dengan TI-KOM $10 \%$, namun tidak berbeda dibandingkan dengan TI-PRO-BK $10 \%$. Hasil ini memberi gambaran bahwa ayam akan memberikan respons pertumbuhan yang lebih baik terhadap ransum yang mengandung TI-PRO-BK dan TI-PRO-BIS, walaupun kandungan protein kasar pada kedua tepung ikan tersebut lebih rendah dibandingkan TI-KOM. Pada Tabel 1 dapat dilihat bahwa kandungan protein kasar TI-PRO-BIS (57,15\%) lebih rendah baik dibandingkan dengan TI-PROBK (62,38\%) maupun TI-KOM (65,98\%). Demikian pula dilihat dari kandungan asam aminonya, secara keseluruhan TI-PRO-BIS mengandung asam- amino yang lebih rendah dibandingkan dengan TI-PRO-BK dan TI-KOM.

\section{Efisiensi Penggunaan Protein}

Salah satu metode untuk menguji kualitas protein di dalam suatu bahan pakan adalah dengan menghitung Protein Efficiency Ratio (PER). Nilai PER diperoleh dari perbandingan antara pertambahan bobot badan dengan konsumsi protein. Semakin tinggi nilai PER menunjukkan semakin efisien seekor ternak mengkonversi protein pakan menjadi protein tubuh. Rataan PER ransum yang mengandung TI-PRO disajikan pada Gambar 1. 


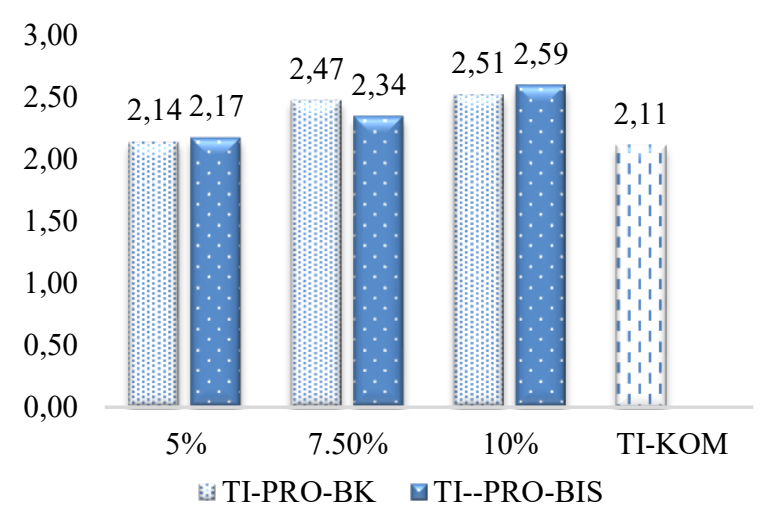

Gambar 1. Protein Efisiensi Ratio

Jenis TI-PRO tidak memberikan pengaruh terhadap PER, sedangkan taraf penggunaan TIPRO secara nyata $(P<0,05)$ dapat meningkatkan PER. Semakin tinggi taraf penggunaan TI-PRO maka nilai PER akan sema kin meningkat. Penggunaan TI-PRO-BIS 10\% menghasilkan PER yang relative sama dengan TIPRO-BK $10 \%$, $(2,59$ vs 2,52$)$ dan nyata lebih tinggi dibandingkan dengan TI-KOM 10\% $(2,11)$. Sementara itu penggunaan TI-PRO-BK 10\% tidak berbeda nyata dibandingkan dengan TI-KOM. Nilai PER yang diperoleh pada penelitian ini mendekati nilai PER pakan komersil dengan penambahan probiotik, yaitu berkisar 2,51-2,57 (Hendalia et al., 2012).

Secara teoritis, utilisasi nutrient, khususnya protein kasar sangat berkaitan dengan kualitas protein dan keseimbangan asam amino di dalam pakan. Bila diamati dari komposisi nutrient yang dikandungnya (Tabel 1), terlihat bahwa secara keseluruhan kandungan protein dan asam amino esensial (AAE) pada TI-PRO-BIS lebih rendah dibandingkan dengan TI-PRO-BK dan TIKOM, namun sebaliknya dari hasil feeding trial terlihat bahwa ayam yang diberi TI-PRO-BIS $10 \%$ dan TI-PRO-BK $10 \%$ menunjukkan performans yang lebih baik dibandingkan dengan ayam yang diberi TI-KOM $10 \%$. Sejalan dengan penjelasan sebelumnya, peningkatan efisiensi penggunaan protein (PER) pada ayam yang diberi TI-PRO selain disebabkan oleh metode pengolahannya yang tidak menggunakan panas, juga dapat disebabkan oleh adanya peran metabolit postbiotik yang diproduksi oleh BAL. Keberadaan probiotik, prebiotik dan postbiotik di dalam tepung ikan, dapat berperan sebagai feed additive sehingga proses penyerapan nutrien, termasuk protein menjadi lebih efisien (Patterson dan Burkholder, 2003; Loh et al., 2014; Lim et al., 2016)

\section{Bobot Potong, Bobot Karkas dan Bobot Daging Dada}

Rataan bobot potong, bobot karkas dan bobot daging dada pada ayam yang diberi TI-PRO dapat dilihat pada Tabel 4.

Pada Tabel 4 dapat dilihat bahwa secara keseluruhan, penggunaan TI-PRO-BIS menghasilkan rataan bobot potong (BP), bobot karkas mutlak (BKM), bobot karkas relative (BKR) dan bobot daging dada (BDD) yang relative lebih tinggi dibandingkan dengan TIPRO-BK, namun perbedaan yang nyata hanya terlihat pada bobot karkas mutlak (BKM). Hasil ini mengindikasikan bahwa kualitas TI-PRO-BIS relatif lebih baik dibandingkan dengan kualitas TI-PRO-BK. Indikasi ini terlihat dari data sebelumnya (interaksi antara jenis dan taraf penggunaan), dimana penggunaan TI-PRO-BIS $10 \%$ menghasilkan performans pertumbuhan yang nyata lebih tinggi dibandingkan dengan TI-KOM $10 \%$,

Taraf penggunaan TI-PRO akan diikuti oleh peningkatan BP, BKM dan BDD, namun peningkatan yang nyata baru terlihat pada taraf penggunaan TI-PRO 10\%. Hasil ini juga memperkuat dugaan sebelumnya bahwa kualitas nutrisi TI-PRO lebih baik dibandingkan dengan kualitas TI-KOM, sehingga semakin tinggi taraf penggantian TI-KOM dengan TI-PRO akan berdampak positif terhadap semua parameter yang diamati. Tidak terdapat interaksi antara jenis dan taraf penggunaan TI-PRO, namun dari hasil analisis satu arah terlihat bahwa penggunan TIPRO-BIS 10\% menghasilkan BP, BKM dan BDD yang nyata lebih tinggi dibandingkan dengan TIPRO-BK 10\% dan TI-KOM 10\% (kontrol).

$$
\text { Penggunaan TI-PRO-BK } \quad 10 \%
$$
menghasilkan BKM yang relatif sama dengan penggunaan TI-KOM 10\%, namun nyata menghasilkan BP dan BDD yang lebih tinggi dibandingkan dengan TI-KOM 10\%. Dengan demikian, dari data keseluruhan terdapat indikasi bahwa kualitas biologis TI-PRO-BK ada di bawah TI-PRO-BIS, namun kualitas keduanya lebih baik dibandingkan dengan TI-KOM.

Keunggulan yang ditunjukkan oleh penggunaan TI-PRO-BIS dan TI-PRO-BK dibandingkan dengan TI-KOM membuktikan bahwa kandungan nutrient yang lebih tinggi pada TI-KOM (Tabel 1) tidak menjamin dihasilkannya pertumbuhan ayam yang lebih baik. 
Tabel 4. Bobot potong, bobot karkas dan bobot daging dada pada ayam broiler yang diberi TI- PROBK, TI-PRO-BIS dan TI-KOM

\begin{tabular}{|c|c|c|c|c|}
\hline \multirow[t]{2}{*}{ Perlakuan } & \multirow{2}{*}{$\begin{array}{l}\text { Bobot potong } \\
\text { (g/ekor) }\end{array}$} & \multicolumn{2}{|c|}{ Bobot karkas } & \multirow{2}{*}{$\begin{array}{l}\text { Bobot daging } \\
\text { dada (g/ekor) }\end{array}$} \\
\hline & & Mutlak (g/ekor) & Relatif (\%) & \\
\hline Jenis TI-PRO (A) & $P>0.05$ & $\mathrm{P}<0.05$ & $P>0.05$ & $P>0.05$ \\
\hline TI-PRO-BK & $679.00 \pm 137.26$ & $443.84^{\mathrm{a}} \pm 113.24$ & $65.11 \pm 7.63$ & $110.25 \pm 31.63$ \\
\hline TI-PRO-BIS & $765.47 \pm 200.52$ & $532.13^{b} \pm 141.73$ & $69.48 \pm 6.56$ & $127.07 \pm 33.88$ \\
\hline Taraf penggunaan (B) & $\mathbf{P}<\mathbf{0 . 0 5}$ & $\mathbf{P}<\mathbf{0 . 0 5}$ & $P>0.05$ & $\mathbf{P}<\mathbf{0 . 0 5}$ \\
\hline TI-PRO-5\% & $679.62^{a} \pm 157.29$ & $472.87^{\mathrm{a}} \pm 137.39$ & $69.10 \pm 7.09$ & $117.50^{\mathrm{a}} \pm 11.65$ \\
\hline TI-PRO-7,5\% & $748.62^{\mathrm{ab}} \pm 100.77$ & $482.06^{\mathrm{a}} \pm 116.38$ & $64.09 \pm 10.65$ & $119.00^{\mathrm{a}} \pm 23.00$ \\
\hline TI-PRO-10\% & $883.00^{\mathrm{b}} \pm 139.29$ & $609.69^{b} \pm 105.79$ & $69.23 \pm 6.4$ & $149.50^{b} \pm 36.94$ \\
\hline Interaksi (A x B) & $P>0.05$ & $P>0.05$ & $P>0.05$ & $P>0.05$ \\
\hline TI-PRO-BK 5\% & $654.50^{\mathrm{ab}} \pm 189.88$ & $437.37^{\mathrm{a}} \pm 139.87$ & $66.30 \pm 2.87$ & $115.00^{\mathrm{ab}} \pm 14.90$ \\
\hline TI-PRO-BK 7,5\% & $732.87^{\mathrm{ab}} \pm 73.23$ & $449.62^{\mathrm{a}} \pm 134.23$ & $60.88 \pm 15.30$ & $118.25^{\mathrm{b}} \pm 23.54$ \\
\hline TI-PRO-BK 10\% & $775.75^{\mathrm{b}} \pm 105.15$ & $525.87^{\mathrm{a}} \pm 60.40$ & $67.93 \pm 1.48$ & $127.75^{b} \pm 41.29$ \\
\hline TI-PRO-BIS 5\% & $704.75^{\mathrm{ab}} \pm 173.70$ & $508.37^{\mathrm{a}} \pm 145.34$ & $71.90 \pm 9.38$ & $120.00^{\mathrm{b}} \pm 8.83$ \\
\hline TI-PRO-BIS 7,5\% & $764.37^{\mathrm{b}} \pm 153.56$ & $514.50^{\mathrm{a}} \pm 103.83$ & $67.29 \pm 1.78$ & $119.75^{b} \pm 26.04$ \\
\hline TI-PRO-BIS 10\% & $990.25^{c} \pm 91.34$ & $693.50^{b} \pm 61.13$ & $70.53 \pm 9.52$ & $171.25^{c} \pm 14.75$ \\
\hline Control & $\mathrm{P}<0.05$ & $\mathrm{P}<0.05$ & $P>0.05$ & $\mathrm{P}<0.05$ \\
\hline TI-KOM 10\% & $550.86^{\mathrm{a}} \pm 83.74$ & $366.64^{a} \pm 64.34$ & $66.39 \pm 2.70$ & $83.14^{\mathrm{a}} \pm 20.88$ \\
\hline
\end{tabular}

Keterangan: Huruf yang berbeda pada kolom yang sama menunjukkan perbedaan yang nyata $(\mathrm{P}<0,05)$.

TI-PRO-BK = Tepung ikan rucah yang diolah menggunakan probiotik BAL dengan sumber prebiotic BK; TIPRO-BIS = Tepung ikan rucah yang diolah menggunakan Probiotik BAL dengan sumber prebiotik BIS

Pada Tabel 2 dapat dilihat bahwa kandungan protein kasar ransum pada perlakuan TI-PRO-BIS $10 \%$ dan TI-PRO-BK relatif lebih rendah dibandingkan dengan kandungan protein kasar ransum kontrol TI-KOM $10 \%$, namun secara biologis penggunaan TI-PRO-BIS 10\% dan TI-PRO-BK $10 \%$ mampu menghasilkan pertumbuhan ayam yang lebih baik dibandingkan dengan penggunaan TI-KOM $10 \%$.

\section{Jumlah Lactobacillus sp. dan E. coli di dalam Cairan Usus}

Jenis TI-PRO, taraf penggunaan TI-PRO dan interaksinya tidak memberikan pengaruh terhadap jumlah Lactobacillus sp, E.coli dan $\mathrm{pH}$ cairan usus. Data pada Tabel 5 menunjukkan bahwa secara keseluruhan jumlah Lactobacillus sp. di dalam isi usus ayam yang diberi TI-PROBK, TI-PRO-BIS dan TI-KOM pada taraf $10 \%$ berada pada kisaran logaritma $10 \mathrm{cfu} / \mathrm{ml}$ dengan nilai $\mathrm{pH}$ masing-masing $5.77 \pm 0,14 ; 5.87 \pm 0,26$ dan $5.64 \pm 0,33$. Nilai $\mathrm{pH}$ bakteri asam laktat sangat erat hubungannya dengan jumlah bakteri asam laktat (Manin et al., 2018) karena Lactobacillus sp akan memproduksi asam laktat yang berperan untuk menurunkan $\mathrm{pH}$ (Lopez, 2000).

Tidak adanya perbedaan jumlah Lactobacillus pada ayam yang diberi TI-PRO dengan ayam yang diberi TI-KOM disebabkan bahan pakan yang digunakan dalam penyusunan ransum relatif sama, terutama bungkil kedele yang merupakan sumber prebiotik. Manin et al. (2013) melaporkan bahwa BAL dapat tumbuh dengan baik pada media bungkil kedelai dengan konsentrasi Log $11-\log 12 \mathrm{cfu} / \mathrm{gr}$. Dengan demikian penggunaan bungkil kedele akan mendukung perkembangan Lactobacillus di dalam saluran pencernaan ternak, sekalipun bakteri tersebut tidak ditambahkan ke dalam ransum. Dilaporkan oleh Natsir (2016), bahwa jumlah Lactobacillus sp pada isi saluran usus ayam broiler berada pada kisaran Log 6,96 - Log 8,35 .

Nilai $\mathrm{pH}$ isi usus yang relative sama pada ayam yang diberi TI-PRO_BK 10\%, TI-PRO-BIS $10 \%$ dan TI-KOM $10 \%$ sejalan dengan tidak adanya perbedaan antara jumlah Lactobacillus sp. pada masing-masing perlakuan tersebut. Nilai $\mathrm{pH}$ bakteri asam laktat sangat erat hubungannya dengan jumlah bakteri asam laktat (Manin et al., 2018) karena Lactobacillus sp akan memproduksi asam laktat yang berperan untuk menurunkan $\mathrm{pH}$ (Lopez, 2000). Nilai $\mathrm{pH}$ isi usus ayam pada penelitian ini lebih rendah dibandingkan dengan yang dilaporkan oleh Natsir (2016) bahwa $\mathrm{pH}$ isi usus ayam broiler yang tidak diberi perlakuan adalah 6,41 , sedangkan yang diberi perlakuan berkisar 6,31- 6,93. 
Tabel 5. Pengaruh Perlakuan terhadap Jumlah Lactobacillus sp., E. Coli dan pH cairan usus

\begin{tabular}{llll}
\hline Perlakuan & $\begin{array}{c}\text { Lactobacillus } \mathrm{sp} \\
(\text { Log cfu/ml) }\end{array}$ & $\begin{array}{l}\text { E. coli } \\
\text { (Log cfu/ml) }\end{array}$ & $\mathrm{pH}$ \\
\hline Jenis TI-PRO (A) & $\mathbf{P}>\mathbf{0 , 0 5}$ & $\mathbf{P}>\mathbf{0 , 0 5}$ & $\mathbf{P}>\mathbf{0 , 0 5}$ \\
TI-PRO-BK & $10.63^{\mathrm{a}} \pm 0,79$ & $7.06 \pm 0,92$ & $5.77 \pm 0,27$ \\
TI-PRO-BIS & $10.11^{\mathrm{b}} \pm 0,83$ & $6.58 \pm 0,61$ & $5.75 \pm 0,41$ \\
Taraf (B) & $\mathbf{P}>\mathbf{0 , 0 5 6}$ & $\mathbf{P}>\mathbf{0 , 0 5}$ & $\mathbf{P}>\mathbf{0 , 0 5}$ \\
TI-PRO-5\% & $10.47 \pm 0,70$ & $7.04 \pm 0,74$ & $5.81 \pm 0,45$ \\
TI-PRO-7,5\% & $9.86 \pm 1,05$ & $6.47 \pm 0,78$ & $5.75 \pm 0,35$ \\
TI-PRO-10\% & $10.75 \pm 0,53$ & $6.89 \pm 0,79$ & $5.82 \pm 0,20$ \\
Interaksi (A x B) & $\mathbf{P}<\mathbf{0 , 0 5}$ & $\mathbf{P}>\mathbf{0 , 0 5}$ & $\mathbf{P}>\mathbf{0 , 0 5}$ \\
TI-PRO-BK 5\% & $10.18^{\mathrm{ab}} \pm 0,80$ & $7.26 \pm 0,69$ & $5.84 \pm 0,29$ \\
TI-PRO-BK 7,5\% & $10.56^{\mathrm{a}} \pm 1,31$ & $6.64 \pm 1,06$ & $5.89 \pm 0,23$ \\
TI-PRO-BK 10\% & $10.79^{\mathrm{a}} \pm 0,62$ & $7.29 \pm 0,76$ & $5.77 \pm 0,14$ \\
TI-PRO-BIS 5\% & $10.75^{\mathrm{a}} \pm 0,56$ & $6.82 \pm 0,81$ & $5.78 \pm 0,62$ \\
TI-PRO-BIS 7,5\% & $9.17^{\mathrm{b}} \pm 0,15$ & $6.31 \pm 0,47$ & $5.60 \pm 0,42$ \\
TI-PRO-BIS 10\% & $10.70^{\mathrm{a}} \pm 0,51$ & $6.48 \pm 0,6$ & $5.87 \pm 0,26$ \\
Control & $\mathbf{P}>\mathbf{0 , 0 5}$ & $\mathbf{P}>\mathbf{0 , 0 5}$ & $\mathbf{P}>\mathbf{0 , 0 5}$ \\
TI-KOM & $10.44^{\mathrm{a}} \pm 0,87$ & $6.92 \pm 0,98$ & $5.64 \pm 0,33$ \\
\hline
\end{tabular}

Keterangan: Huruf yang berbeda pada kolom yang sama menunjukkan perbedaan yang nyata $(\mathrm{P}<0,05)$

TI-PRO-BK $=$ Tepung ikan rucah yang diolah menggunakan BAL dengan sumber prebiotic BK; TI-PRO-BIS = Tepung ikan rucah yang diolah menggunakan BAL dengan sumber prebiotik BIS

Jumlah E. Coli di dalam isi usus halus tidak dipengaruhi secara nyata oleh jenis TI-PRO, taraf penggunaan dan interaksi antar keduanya. Kondisi ini menunjukkan bahwa perlakuan belum dapat menghambat pertumbuhan E. Coli di dalam saluran pencernaan ayam, sekalipun jumlah Lactobacillus sp. di dalam isi saluran pencernaan tersebut berada pada kisaran $10^{10} \mathrm{cfu} / \mathrm{ml}$. Hasil ini sejalan dengan hasil penelitian Manin et al. (2014b) bahwa tidak terdapat perbedaan yang signifikan antara $\mathrm{pH}$, jumlah bakteri Lactobacillus, E.coli dan Salmonella pada itik yang diberi probiotik melalui air minum, pakan dan gabungan air minum dan pakan.

\section{KESIMPULAN}

Berdasarkan hasil penelitian dapat disimpulkan bahwa tepung ikan rucah yang diolah menggunakan probiotik bakteri asam laktat dikombinasikan dengan precursor prebiotik berupa bungkil kelapa (TI-PRO-BK) atau bungkil int sawit (TI-PRO-BIS), memiliki kualitas nutrisi yang lebih baik dibandingkan dengan tepung ikan komersil (TI-KOM), sehingga berpotensi untuk digunakan sebagai sumber protein sekaligus sumber probiotik, prebiotik dan postbiotic dalam ransum unggas, khususnya ayam broiler.

\section{UCAPAN TERIMA KASIH}

Penulis mengucapkan terima kasih kepada Direktur Riset dan Pengabdian kepada Masyarakat, Direktorat Jenderal Penguatan Riset dan Pengembangan, Kementerian Riset,
Teknologi, dan Pendidikan Tinggi yang mendanai penelitian ini sesuai dengan kontrak penelitian Nomor B/77/UN21.18/PT.0103/2019, tahun anggaran 2019 dan Kepala Lembaga Penelitian dan Pengabdian kepada Masyarakat, Universitas Jambi yang telah memfasilitasi pelaksanaan penelitian ini.

\section{DAFTAR PUSTAKA}

Hidayatulloh, A., J. Gumilar, dan E. Harlia. 2019. Potensi senyawa metabolit yang dihasilkan Lactobacillus plantarum ATCC 8014 sebagai bahan biopreservasi dan anti bakteri pada bahan pangan asal hewan. JITP. 7(2): $1-6$

Chuah, L. O., H. L. Foo, T. C. Loh, N. B. Mohammed Alitheen, S. K. Yeap, N. E. Abdul Mutalib, R. Abdul Rahim, and K. Yusoff. 2019. Postbiotic metabolites produced by Lactobacillus plantarum strains exert selective cytotoxicity effects on cancer cells. BMC Complement. Altern. Med. 19:1-12.

Goh, C. H., T. C. Loh, H. L. Foo, and F. Nobilly. 2020. Fecal microbial population and growth in broiler fed organic acids and palm fat-composed diet. Trop. Anim. Sci. J. 43:151-157.

Hendalia, E., F. Manin, Adriani, E. P. Dianti, and A. N. Azizah. 2019a. The Use of Prebiotics and Probiotics in Fish Meal Processing. IOP Conf. Ser. Earth Environ. Sci. 391. 
Hendalia, E., F. Manin, Adriani, Mairizal, and A. R. Admiral. 2019b. Composition and amino acid profile of fish meal processed using probiotics and prebiotic sources. IOP Conf. Ser. Earth Environ. Sci. 387.

Hendalia, E., F. Manin, Yusrizal, dan G. M. Nasution. 2012. Aplikasi probiotik untuk meningkatkan efisiensi penggunaan protein dan menurunkan emisi amonia pada ayam broiler. Agrinak 2:29-35.

Jama, Y. H., and M. C. Varadaraj. 1999. Antibacterial effect of plantaricin LP84 on foodborne pathogenic bacteria occurring as contaminants during idli batter fermentation. World J. Microbiol. Biotechnol. 15:27-32 Available at https://doi.org/10.1023/A:1008887201516.

Lim, T. S., W. N. W. Abdullah, and M. T. Liong. 2016. Application of probiotics for the production of safe and high-quality poultry meat. Korean J. Food Sci. Anim. Resour. 36:567-576.

Loh, T. C., D. W. Choe, H. L. Foo, A. Q. Sazili, and M. H. Bejo. 2014. Effects of feeding different postbiotic metabolite combinations produced by Lactobacillus plantarum strains on egg quality and production performance, faecal parameters and plasma cholesterol in laying hens. BMC Vet. Res. 10:1-9.

Lopez, J. 2000. Probiotic in animal nutrition. Asian-Australian J. Anim. Sci. 55:12381246.

Manin, F., E. Hendalia, dan N. Aziz. 2018. Produksi probiotik Probio_FM powder dengan menggunakan berbagai bahan prebiotik. Laporan Penelitian, Universitas Jambi. Jambi.

Manin, F., E. Hendalia, dan N. Aziz. 2019. Uji coba produk probiotik Probio FM powder dalam air minum terhadap penampilan ayam pedaging dan kadar kolesterol total, Trigliserida, HDL dan LDL. Laporan Penelitian. Universitas Jambi, Jambi.

Manin, F. 2010. Potensi Lactobacillus Acidophilus Dan Lactobacillus Fermentum
Dari Saluran Pencernaan Ayam Buras Asal Lahan Gambut Sebagai Sumber Probiotik. J. Ilm. Ilmu-ilmu Peternak. XIII:221-228.

Manin, F., E. Hendalia, R. Asra, dan Helda 2014a. Pengembangan industri produk probiotik Probio_FM berbasis kemitraan. Laporan Penelitian. Universitas Jambi. Jambi.

Manin, F., E. Hendalia, Yatno, dan P. Rahayu. 2014b. Dampak pemberian probiotik Probio FM terhadap status kesehatan ternak itik kerinci. J. Ilmu Ternak 1:7-11.

Natsir, M. H., E. Widodo dan Muharlien. 2016. Penggunaan kombinasi kunyit (Curcuma domestica) dan jahe (Zingiber officinale) bentuk enkapsulasi dan tanpa enkapsulasi terhadap karakteristik usus dan mikroflora usus ayam pedaging. Buletin Peternakan, 40 (1): $1-10$

Patterson, J., and K. Burkholder. 2003. Application of prebiotics and probiotics in poultry production. Poult. Sci. 82:627-631.

Sundu, B., A. Kumar, and J. Dingle. 2006. Palm kernel meal in broiler diets: effect on chicken performance and health. Worlds. Poult. Sci. J. 62:316-325.

Thanh, N. T., T. C. Loh, H. L. Foo, M. Hair-Bejo, and B. K. AZHAR. 2009. Effects of feeding metabolite combinations produced by Lactobacillus plantarum on growth performance, faecal microbial population, small intestine villus height and faecal volatile fatty acids in broilers. Br. Poult. Sci. 50:298-306.

Thu, T. Van, H. L. Foo, T. C. Loh, and M. H. Bejo. 2011. Inhibitory activity and organic acid concentrations of metabolite combinations produced by various strains of Lactobacillus plantarum. African J. Biotechnol. 10:1359-1363.

Yang, S. J., K. T. Kim, T. Y. Kim, and H. D. Paik. 2020. Probiotic properties and antioxidant activities of Pediococcus pentosaceus SC28 and Levilactobacillus brevis KU15151 in fermented black gamju. Foods 9. 